\title{
Polyploid spermatozoa in Pityogenes chalcographus and Ips typographus (Coleoptera: Scolytidae)
}

\author{
ERWIN FÜHRER \\ Institute of Forest Entomology, Pathology and Protection, BOKU - University of Natural Resources and Applied Life Sciences, \\ Vienna, Hasenauerstrasse 38, A-1190 Vienna, Austria; e-mail: fuehrer@ento.boku.ac.at
}

Key words. Pityogenes chalcographus, Ips typographus, spermatozoa, polyploidy, allopatric crosses, incompatibility

\begin{abstract}
Abnormal spermatogenesis in Pityogenes chalcographus (L.) and Ips typographus (L.) results in oversized spermatozoa in all the populations investigated. They can be identified by light microscopy and classified as $2 \mathrm{n}$ up to $16 \mathrm{n}$ polyploid. The percentage of polyploid sperm increases when allopatric parents are crossed: Parental populations with less than $1 \%$ polyploid, result in male $\mathrm{F}_{1}$ with more than $20 \%$ polyploid. Wild populations of P. chalcographus and I. typographus have very different percentages of polyploid sperm. Populations from allochthonous sites for the host tree, Picea abies (Karst.), are distinguished by higher rates of sperm polyploidy than those from autochthonous areas. Thus, it is assumed that polyploid sperm indicates populations originating from the mixing of partially incompatible beetles.
\end{abstract}

\section{INTRODUCTION}

The northward migration of Norway spruce (Picea abies Karsten) within Europe after the last ice age has received much interest. After limitation to a few areas of refuge, the remigration to North and Central Europe resulted in a differentiation of Nordic-Baltic, HercynianKarpathian, and Alpine regions of distribution and a corresponding increase in genetic diversity (Schmidt-Vogt, 1974; Lagercrantz \& Ryman, 1990; Giannini et al., 1991). It is assumed that the herbivorous insects, which are dependent on $P$. abies, followed their host plant to the North and West. Spreading with their host plant, they either remained ecologically flexible, or differentiated genetically depending on the ecosystem of their host (Stauffer et al., 1999).

Spruce bark beetles (Col.: Scolytidae) are good examples of the widely distributed specialised herbivores that are adjusted to the distribution of their host plant, $P$. abies. There are different ecotypes of these beetles in Europe. Pityogenes chalcographus (L.) populations in North and Central Europe differ in morphological characteristics, food preference, ethological habits and reproductive compatibility (Führer, 1977, 1978; Sturies \& Führer, 1979; Führer \& Mühlenbrock, 1983). Allopatric crosses between Scandinavian and Alpine populations reveal a partial incompatibility and divergent ecological potential of the $F_{1}$ hybrids (Führer \& Klipstein, 1980; Klipstein, 1983; Führer, 1984). Similar phenomena are recorded in Ips typographus (L.), whose populations show typical voltinism and pheromone responses (Leitinger \& Schreiber, 1992, Hösle et al., 2000). This is further supported by genetic investigations using isoenzyme and DNA techniques, which also give an insight into the phylogeography of spruce bark beetles in Europe (Ritzengruber \& Führer, 1986; Ritzengruber, 1990; Stauffer et al., 1992, 1999).
In the past human activities have mixed originally isolated populations of bark beetles and geneticists attempt to investigate the phylogeography of these insects within their present distribution. I have examined a cytological method by which allochthonous from autochthonous populations can be distinguished. Spermatogenesis is a suitable tool for this purpose because each male produces large amounts of spermatozoa, which is easily studied after staining.

In $P$. chalcographus, the male karyotype is $2 \mathrm{n}=18+$ Xyp, while in I. typographus, as in other species of the genus Ips (Lanier, 1970), the male karyotype is $2 \mathrm{n}=30+$ $\mathrm{Xy}$. Apart from this genus-related difference, which is typical of various genera of Scolytidae (Virkki, 1960), the karyology of bark beetles is more intricate because of the pseudogamy of some Ips species with triploid females (Lanier \& Kirkendall, 1986). Size of spermatozoa is typical for a species and not related to the karyotype: $P$. chalcographus has larger sperm than I. typographus.

In the current study, the hypothesis that spermatozoa of $P$. chalcographus and I. typographus in autochthonous populations are uniform, while abnormities in spermatogenesis may occur in populations of mixed origin, was tested. A part of the results of my studies on polyploid spermatozoa in P. chalcographus is published (Führer, 1980; Führer \& Krehan, 1985). Here, the essential points are briefly repeated and complemented by important facts. The results of the study on $P$. chalcographus support the hypothesis. Moreover, the results for $P$. chalcographus should be considered together with those for $I$. typographus. Thus, this paper includes a report of an investigation on wild populations of I. typographus that was carried out in order to determine whether this phenomenon also occurs in this species. 
TABLE 1. Origin of the wild populations of $P$. chalcographus and I. typographus.

\begin{tabular}{|c|c|c|}
\hline $\begin{array}{l}\text { Spruce } \\
\text { region }\end{array}$ & $\begin{array}{l}\text { Origin of } P . \text { chalcographus } \\
\text { populations }\end{array}$ & $\begin{array}{l}\text { Origin of I. typogra- } \\
\text { phus populations }\end{array}$ \\
\hline \multirow[t]{3}{*}{$\begin{array}{l}\text { Nordic- } \\
\text { Baltic }\end{array}$} & $\begin{array}{r}\text { Finland: Vuohiniämi (VI) } \\
\text { Ruotsinkylä (RÄ) }\end{array}$ & - \\
\hline & Norway: Eidskog (NO) & \\
\hline & Poland: Bialowieza (WA) & \\
\hline \multirow[t]{2}{*}{ Hercynian } & Poland: Rudziniec (PL) & Slovakia: Tatra Mts \\
\hline & Germany: St. Andreasberg (AB) & \\
\hline $\begin{array}{l}\text { Foothill } \\
\text { zone }\end{array}$ & Czech Republic: Kostelec & $\begin{array}{l}\text { Germany: Weihen- } \\
\text { stephan }\end{array}$ \\
\hline $\begin{array}{l}\text { Near } \\
\text { Hercynian }\end{array}$ & Germany: Schleswig & $\begin{array}{l}\text { Austria: Aigen } \\
\text { Schlägl }\end{array}$ \\
\hline \multirow[t]{8}{*}{ region } & Bayerischer Wald (BW) & \\
\hline & $\begin{array}{l}\text { Austria: Aigen Schlägl (AI, AS, } \\
\text { SS) }\end{array}$ & \\
\hline & $\begin{array}{l}\text { Mühlviertel-Weitersfelden } \\
\text { (MW) }\end{array}$ & \\
\hline & Grein/Donau (GN) & \\
\hline & Ostrong (OS) & \\
\hline & Persenbeug (PE) & \\
\hline & Litschau (LI) & \\
\hline & Zwettl (WI) & \\
\hline $\begin{array}{l}\text { Foothill } \\
\text { zone }\end{array}$ & $\begin{array}{l}\text { Germany: Baindt/Oberschwaben } \\
\text { (SW) }\end{array}$ & $\begin{array}{l}\text { Switzerland: Bir- } \\
\text { mensdorf }\end{array}$ \\
\hline near Alpine & Austria: Kobernausser Wald (KW) & Hungary: Köszeg \\
\hline \multirow[t]{3}{*}{ region } & Eferding (EF) & Austria: Flatz \\
\hline & Wieselburg (WB) & Prinzersdorf \\
\hline & & Fürstenfeld \\
\hline \multirow[t]{6}{*}{ Alpine } & Austria: Grossreifling (GG) & Austria: Altmünster \\
\hline & Altenmarkt (ST) & $\begin{array}{l}\text { Nationalpark } \\
\text { Kalkalpen }\end{array}$ \\
\hline & Windischgarsten (WG) & Gesäuse \\
\hline & Hinterstoder (HS) & Rothwald \\
\hline & Frohnleiten (FN) & \\
\hline & Eisenkappel (EK) & \\
\hline
\end{tabular}

\section{MATERIALS AND METHODS}

Populations of $P$. chalcographus from Finland, Norway, Poland, North and South Germany and Austria were kept in the laboratory and used for crossing experiments as described in Führer (1977). Wild populations of this species were collected in Austria and the Czech Republic by bringing pieces of infested boles to the laboratory. The emerging beetles supplied the material for this study. The different provenances of the populations of $P$. chalcographus are described in Führer \& Krehan (1985). Here they are briefly quoted and supplemented with similar data on I. typographus (Table 1).

The pronounced sexual dimorphism of $P$. chalcographus enabled reciprocal crosses between individuals from two populations ( 20 ot 0 from population A were mated with 20 우 from population B and $20 \hat{\delta} \delta$ from B with $20 \% q$ from A). Sex in I. typographus was determined by dissection. Generally, at least 20 male beetles per population were inspected. They were obtained from colonies from reciprocal crosses maintained in the laboratory, or from infested spruce boles in the field. The testes were dissected from individual beetles in RINGER's saline under a microscope. The isolated testes were squashed and stained with GIEMSA's solution or with aceto-orcein stain (Romeis, 1968) and examined under light microscopy at 1000x.
TABLE 2. Sizes of haploid and polyploid spermatozoa (mean, standard deviation) of $P$. chalcographus and I. typographus. In one beetle of I. typographus (Flatz) nearly all the spermatozoa were oversized. (Significance difference in head lengths $=P<$ 0.001 for all ploidy categories. Head volume and tail length are approximate values only.)

\begin{tabular}{lccccc}
\hline Species & $\begin{array}{c}\text { Sample } \\
\text { size N }\end{array}$ & & \multicolumn{1}{c}{$\begin{array}{c}\text { length } \\
\mu \mathrm{m}\end{array}$} & $\begin{array}{c}\text { Head } \\
\text { volume } \\
\mu \mathrm{m}^{3}\end{array}$ & $\begin{array}{c}\text { Tail length } \\
\mu \mathrm{m}\end{array}$ \\
\hline Pityogenes & 47 & $\mathrm{n}$ & $11.8 \pm 0.3$ & 2.0 & $68.1 \pm 4.6$ \\
& 85 & $2 \mathrm{n}$ & $15.7 \pm 0.9$ & 4.1 & $65.3 \pm 5.8$ \\
& 18 & $4 \mathrm{n}$ & $20.4 \pm 1.1$ & 9.0 & $67.5 \pm 3.2$ \\
& 3 & $8 \mathrm{n}$ & $24.3 \pm 0.8$ & 16.3 & $62.0 \pm 2.7$ \\
Ips & 171 & $\mathrm{n}$ & $6.9 \pm 0.6$ & 0.5 & $130.9 \pm 7.0$ \\
& 53 & $2 \mathrm{n}$ & $10.4 \pm 0.5$ & 1.1 & $129.9 \pm 10.8$ \\
& 39 & $4 \mathrm{n}$ & $14.1 \pm 1.0$ & 1.9 & $129.7 \pm 9.4$ \\
& 5 & $8 \mathrm{n}$ & $17.2 \pm 0.5$ & 4.0 & $117.0 \pm 0.0$ \\
Ips (Flatz) & 1 & $\mathrm{n}$ & $7.8 \pm 0.0$ & 0.6 & $169.0 \pm 0.0$ \\
& 4 & $2 \mathrm{n}$ & $11.7 \pm 0.0$ & 1.2 & $157.3 \pm 11.2$ \\
& 15 & $4 \mathrm{n}$ & $14.1 \pm 0.4$ & 2.1 & $157.0 \pm 7.1$ \\
& 14 & $8 \mathrm{n}$ & $18.2 \pm 0.8$ & 4.3 & $158.3 \pm 13.8$ \\
& 6 & $16 \mathrm{n}$ & $21.7 \pm 0.6$ & 8.4 & $156.0 \pm 16.9$ \\
\hline
\end{tabular}

Aceto-orcein stained smears showed the different phases of spermatogenesis and the chromosome number, while smears stained with GIEMSA's solution were used to determine the percentage of polyploid sperm. The stained preparations were used to determine the size and shape of single sperm by analysing at least 500 gametes per specimen randomly distributed over a smear. The number of haploid and polyploid spermatozoa was separated by size and counted, after the ploidy was established using aceto-orcein stained smears. An approximate volume of spermatozoa was calculated using the formula volume $=$ length $\times(0.6 \text { width } / 2)^{2} \times \pi$, based on the flattened shape of the cell body on the smear. Since tails of spermatozoa are never straight, their lengths represent approximate values only.

Photomicrographs were taken using Agfa $15^{\circ} \mathrm{DIN}$ or Ilford IP 125 film. For cytophotometry a REICHERT cytophotometer was used. Squashes of testes were stained with FEULGEN (Romeis, 1968) and the round nuclei of the undeveloped spermatid cells were measured, using the two-wave-method (Mendelsohn, 1958). Only individuals from wild populations of $I$. typographus from the Tatra mountains, sites in the Alpine region and the foothill zone of the Alps were investigated.

For statistical analysis the U-test of Wilcoxon, Mann \& Whitney and Student's $t$-test were used (Sachs, 1973).

\section{RESULTS}

\section{Pityogenes chalcographus}

The mature, haploid spermatozoon of $P$. chalcographus has a slender and sharp head that is 11.7 to $12.1 \mu \mathrm{m}$ long, $0.55 \mu \mathrm{m}$ in diameter and $2.0 \mu \mathrm{m}^{3}$ in volume, and a tail 68 $\mu \mathrm{m}$ long. Haploid sperm occurred in most beetles at a percentage of nearly $100 \%$. Larger sperm with a head length of $15.7 \mu \mathrm{m}, 20.4 \mu \mathrm{m}$ or $24.3 \mu \mathrm{m}$ proved to be diploid or polyploid (Fig. 1a-c; Table 2). According to the degree of polyploidy, the sperm had a wider head, although the tail did not exceed the length of that of haploid spermatozoa. 


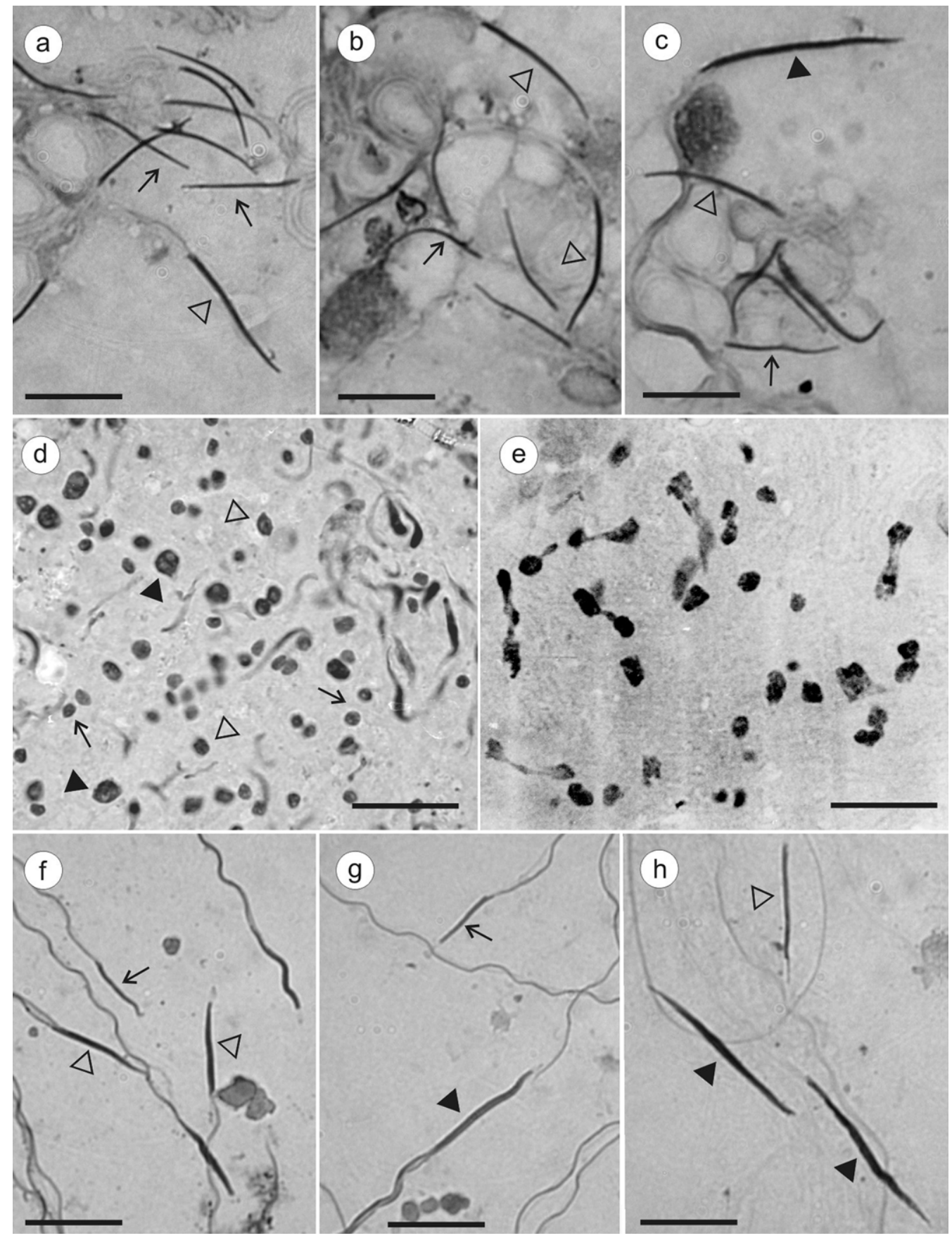

Fig. 1. Haploid $(\uparrow)$, diploid $(\triangle)(\mathrm{a}, \mathrm{b})$ and polyploid $(\mathbf{\Lambda})(\mathrm{c})$ spermatozoa of $P$. chalcographus and I. typographus (f, g). Polyploid sperm of the beetle of I. typographus from Flatz (h). Spermatid nuclei of different ploidy $(\uparrow \triangle \boldsymbol{\Lambda})(\mathrm{d})$ and failed telophases with bridged nuclei (e) in interpopulation male hybrids of $P$. chalcographus. Scale bars $10 \mu \mathrm{m}$.

The tail of polyploid sperm was single and solid but thicker than normal. Diploid and polyploid spermatozoa were scarce in most beetles. In a few cases these sperm were more abundant, i.e. up to $39 \%$ of the total sperm of a male. Cytophotometric measurements (already published in Führer, 1980) show that the nuclei of oversized spermatocytes contain two to eight times the amount of DNA of the normal haploid spermatocytes. This supports the hypothesis that abnormal spermatozoa possess chromosome sets of $2 n$ (sometimes probably $3 n$ ), $4 n$, rarely up to 8 n.
Aceto-orcein stained preparations of interpopulation hybrids indicate the frequent occurrence of bridged nuclei in spermatocytes and the reason for chromosome number multiplication in spermatid nuclei (Fig. 1d, e). The fact that a number of daughter nuclei did not separate completely could be caused by imperfect pairing of chromosomes during meiotic prophase I, resulting in segregation failure after metaphase I.

Oversized spermatozoa were first noticed in some wild populations of $P$. chalcographus. A screening of populations for sperm polyploidy throughout North and Central 


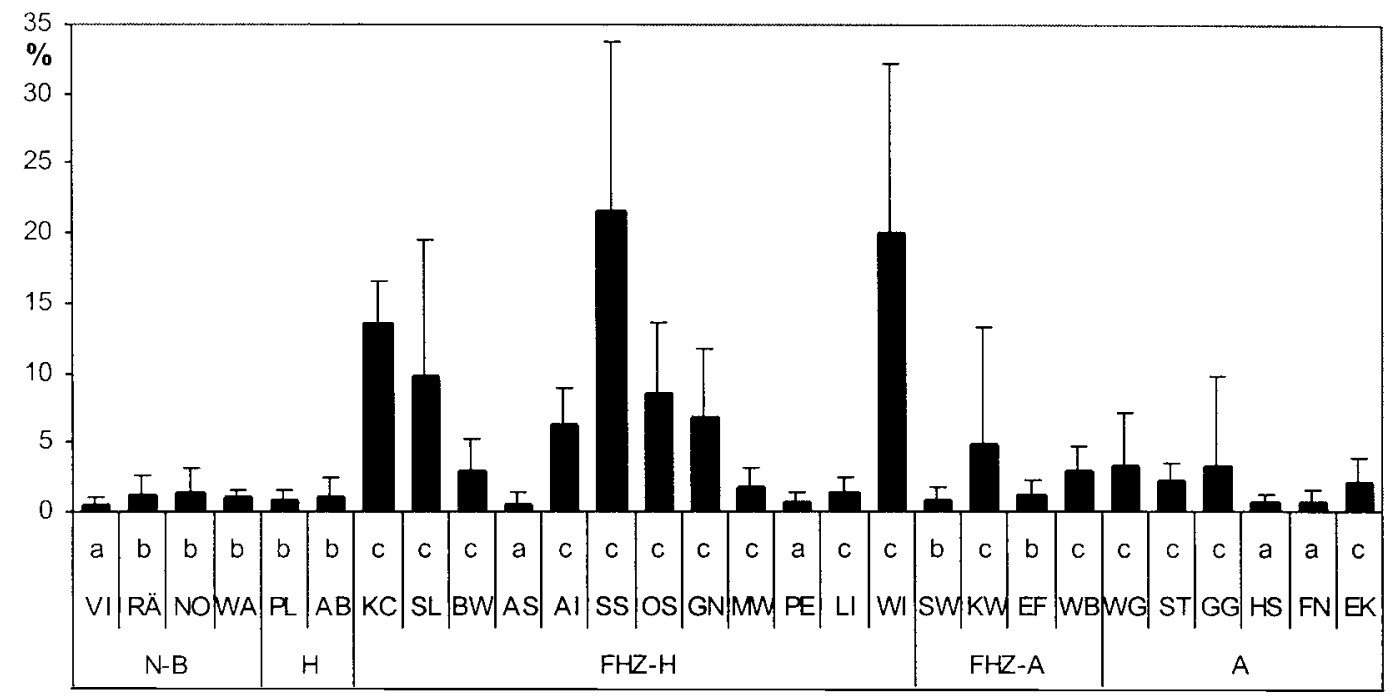

Fig. 2. Percentages of diploid and polyploid spermatozoa in different populations of $P$. chalcographus (mean and standard deviation). Letters indicate levels of significance (to VI): $\mathrm{a}=$ not significant, $\mathrm{b}=P<0.01$, $\mathrm{c}=P<0.001$. For names of populations and spruce regions see Table 1.

Europe showed the uneven occurrence of this phenomenon (Fig. 2). There was a lack of sperm polyploidy in the populations from the Nordic-Baltic and part of the Hercynian area, and in some Alpine populations the percentage of polyploid sperm ranged between 0.6 and 1.5 . However, in the Alps, the foothill zone of the Alps and specially, in the foothill zone round the Hercynian region populations with up to 20.1 percent polyploid sperm were found. The significance of the differences between the populations are specified in Fig. 2.

A more detailed view of the distribution of ploidy in populations in the Central European area (Fig. 3) demon-

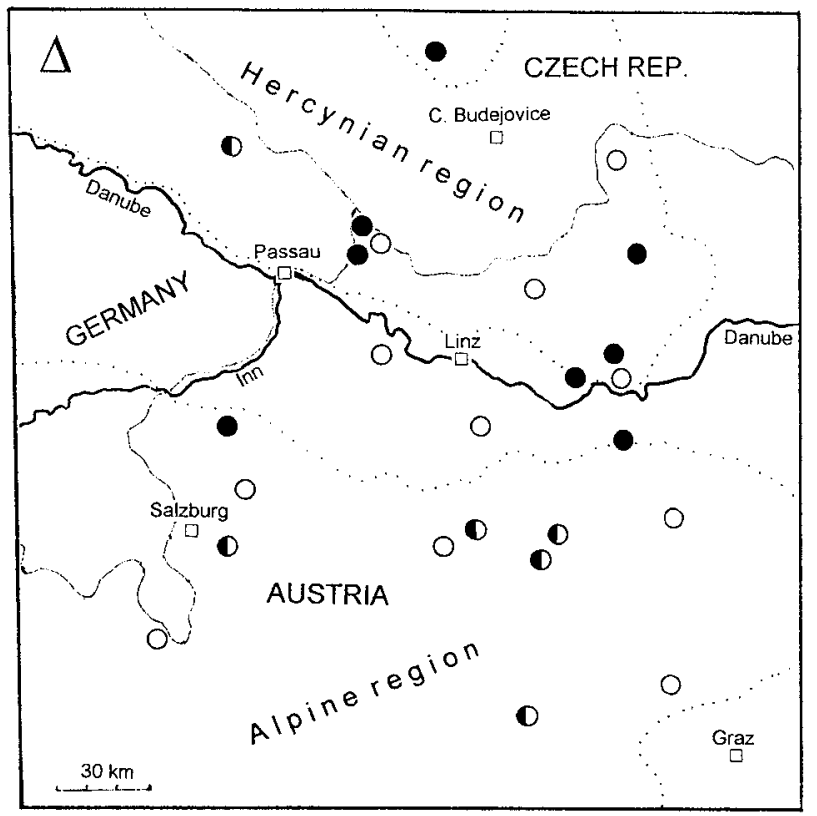

Fig. 3. Sites of $P$. chalcographus populations with low (B), medium $(E)$ and high $(C)$ percentages of polyploid sperm in the Central European area. Border (.....) of the Alpine and Hercynian regions in the formerly spruce-free valley of the Danube (Mayer, 1974). (For levels of significance see Fig. 2.) strates the higher incidence of ploidy in the Hercynian than in the Alpine region. This uneven pattern of polyploidy reminds us of the former invasion of the Hercynian region by spruce from the Alpine region (Mayer, 1974).

Reciprocal crosses of allopatric parents from populations, which had only very low percentages of polyploidy, resulted in nearly all the $F_{1}$ males having significantly higher percentages of polyploid spermatozoa than their parents (Table 3). The smaller the distance in the geographic latitudes of the origins of the parental populations, the more striking was the increase in polyploidy in $F_{1}$ males. The highest polyploidy (59.3\%) was recorded in $\mathrm{F}_{2}$ males from a foothill zone and an Alpine parental population cross.

\section{Ips typographus}

The haploid sperm of $I$. typographus is much smaller than that of $P$. chalcographus: the head is $6.9 \mu \mathrm{m}$ in length and $0.5 \mu \mathrm{m}^{3}$ in volume; the length of the tail is $131.0 \mu \mathrm{m}$ (Fig. 1f, g; Table 2). No significant differences between the populations were found. I. typographus also develops oversized sperm. Detailed measurements of GIEMSA-stained preparations suggest that these spermatozoa should be classified as diploid, tetraploid and octoploid (Table 2). Their heads measure 10.4, 14.1 and $17.2 \mu \mathrm{m}$ in length and 1.1, 1.9 and $4.0 \mu^{3}$ in volume. The tails, however, are the same length as in haploid sperm (129.0 to $117.0 \mu \mathrm{m})$, remaining single and solid; only their thickness increases with the polyploidy. The polyploid sperm of different populations were also of similar size. While nearly all beetles had mainly haploid sperm, one specimen had almost only larger sperm with conspicuously longer tails: 157.3 and $169.0 \mu \mathrm{m}$. Their heads fit approximately the categories mentioned above with the exception of a few spermatozoa that presumably were 16 n (Fig. 1h; Table 2).

The screening of wild populations of $I$. typographus (see Table 1 ) showed that, similar to P. chalcographus, 
TABLE 3. Average percentage of diploid and polyploid spermatozoa in male $\mathrm{F}_{1}$ and $\mathrm{F}_{2}$ hybrids of $P$. chalcographus after crossing of populations from different areas of distribution. $\mathrm{N}=5000$ up to 10000 spermatozoa per sample. FHZ = foothill zone. Mean and standard deviation of parental populations and of crosses. Significant difference between parental populations and crosses: $\mathrm{ns}=\mathrm{not}$ significant, $*=P<0.05, * *=P<0.01, * * *=P<0.001$. Difference in geographical latitude (degrees) of the provenances of the parents used in the crosses.

\begin{tabular}{|c|c|c|c|c|c|}
\hline Generation & $\begin{array}{c}\text { Parental provenances } \\
\qquad \hat{\delta} \times q\end{array}$ & $\begin{array}{l}\text { Areas of spruce } \\
\text { distribution }\end{array}$ & $\begin{array}{l}\text { Percentage diploid } \\
\text { in parental } \\
\text { populations }\end{array}$ & $\begin{array}{l}\text { olyploid sperm } \\
\text { in } F_{1} / F_{2} \\
\text { (significance) }\end{array}$ & $\begin{array}{l}\text { Difference in the } \\
\text { latitude of the } \\
\text { provenances (degrees) }\end{array}$ \\
\hline \multirow[t]{2}{*}{$\mathrm{F}_{1}$} & $\mathrm{RÄ} \times \mathrm{SW}$ & $\mathrm{N}-\mathrm{B} \times \mathrm{FHZ}-\mathrm{A}$ & $1.1 \pm 1.2$ & $3.1 \pm 1.5 * * *$ & 13.0 \\
\hline & $\mathrm{SW} \times \mathrm{RÄ}$ & FHZ-A $\times$ N-B & & $6.8 \pm 4.6 * * *$ & \\
\hline \multirow[t]{2}{*}{$\mathrm{F}_{1}$} & $\mathrm{NO} \times \mathrm{HS}$ & $\mathrm{N}-\mathrm{B} \times \mathrm{A}$ & $1.0 \pm 1.3$ & $2.1 \pm 1.6 \mathrm{~ns}$ & 13.2 \\
\hline & $\mathrm{HS} \times \mathrm{NO}$ & $\mathrm{A} \times \mathrm{N}-\mathrm{B}$ & & $2.1 \pm 1.3 * *$ & \\
\hline \multirow[t]{2}{*}{$\mathrm{F}_{1}$} & $\mathrm{VI} \times \mathrm{PL}$ & $\mathrm{N}-\mathrm{B} \times \mathrm{H}$ & $0.7 \pm 0.6$ & $3.9 \pm 3.9 * *$ & 11.0 \\
\hline & $\mathrm{PL} \times \mathrm{VI}$ & $\mathrm{H} \times \mathrm{N}-\mathrm{B}$ & & $5.0 \pm 3.1 * * *$ & \\
\hline \multirow[t]{2}{*}{$\mathrm{F}_{1}$} & $\mathrm{WA} \times \mathrm{EK}$ & $\mathrm{N}-\mathrm{B} \times \mathrm{A}$ & $1.6 \pm 1.3$ & $4.6 \pm 2.1 * * *$ & 6.5 \\
\hline & $\mathrm{EK} \times \mathrm{WA}$ & $\mathrm{A} \times \mathrm{N}-\mathrm{B}$ & & $2.1 \pm 1.1 *$ & \\
\hline \multirow[t]{2}{*}{$\mathrm{F}_{1}$} & $\mathrm{FN} \times \mathrm{SW}$ & $\mathrm{A} \times \mathrm{FHZ}-\mathrm{A}$ & $0.8 \pm 0.8$ & $20.6 \pm 9.3 * * *$ & 0.7 \\
\hline & $\mathrm{SW} \times \mathrm{FN}$ & $\mathrm{FHZ}-\mathrm{A} \times \mathrm{A}$ & & $14.9 \pm 14.2 * * *$ & \\
\hline \multirow[t]{2}{*}{$\mathrm{F}_{1}$} & $\mathrm{SW} \times \mathrm{HS}$ & $\mathrm{FHZ}-\mathrm{A} \times \mathrm{A}$ & $0.7 \pm 0.7$ & $24.7 \pm 15.5 * * *$ & 0.2 \\
\hline & $\mathrm{HS} \times \mathrm{SW}$ & $\mathrm{A} \times \mathrm{FHZ}-\mathrm{A}$ & & $17.2 \pm 8.6^{* * *}$ & \\
\hline \multirow[t]{2}{*}{$\mathrm{F}_{1}$} & $\mathrm{NO} \times \mathrm{VI}$ & $\mathrm{N}-\mathrm{B} \times \mathrm{N}-\mathrm{B}$ & $0.9 \pm 1.2$ & $10.3 \pm 5.5 * * *$ & 0.0 \\
\hline & $\mathrm{VI} \times \mathrm{NO}$ & $\mathrm{N}-\mathrm{B} \times \mathrm{N}-\mathrm{B}$ & & $14.4 \pm 6.4 * * *$ & \\
\hline \multirow[t]{2}{*}{$\mathrm{F}_{2}$} & $\mathrm{SW} \times \mathrm{HS} \mathrm{X}$ & FHZ-A / A x & $21.0 \pm 12.8$ & $59.3 \pm 5.5 * * *$ & \\
\hline & $\mathrm{SW} \times \mathrm{HS}$ & FHZ-A / A & & & \\
\hline
\end{tabular}

all populations had polyploid spermatozoa in various percentages. Table 4 gives an overview of the frequency of polyploidy in the different populations. The statistical test indicated that three Alpine region populations had the lowest percentage of polyploidy with means of 1.6 to $2.8 \%$, while most of the populations from the foothill zone or from plantations had significantly higher means of 4.3 up to $14.0 \%$. There are two exceptions: the Flatz population, which is not from the Alpine region and has a high value (mean 9.9\%), is not significantly different from that of the Alpine populations because of one specimen with $100 \%$ polyploidy. The second exception is the Alpine population Rothwald (mean 4.4\%). Fig. 4

TABLE 4. Sperm polyploidy in I. typographus populations. Mean percentage, standard deviation, minimum and maximum of polyploidy. Letters indicate different significance levels: $\mathrm{a}=$ not significant, $\mathrm{b}=P<0.01, \mathrm{c}=P<0.001$.

\begin{tabular}{lccccc}
\hline $\begin{array}{l}\text { Origin } \\
\text { of population }\end{array}$ & $\begin{array}{c}\text { beetles } \\
\mathrm{n}\end{array}$ & mean $\pm \mathrm{sd}$ & minimum maximum signif. \\
\hline Tatra & 17 & $1.3 \pm 1.0$ & 0.0 & 3.8 & $\mathrm{a}$ \\
Altmünster & 20 & $1.7 \pm 3.4$ & 0.0 & 15.4 & $\mathrm{a}$ \\
NP Kalkalpen & 42 & $2.2 \pm 3.1$ & 0.0 & 12.2 & $\mathrm{a}$ \\
Gesäuse & 22 & $2.9 \pm 3.1$ & 0.0 & 12.2 & $\mathrm{a}$ \\
Rothwald & 24 & $4.4 \pm 2.7$ & 0.4 & 12.0 & $\mathrm{~b}$ \\
Birmensdorf & 24 & $5.7 \pm 3.5$ & 0.4 & 11.8 & $\mathrm{~b}$ \\
Aigen Schlägl & 21 & $4.4 \pm 3.1$ & 0.8 & 11.0 & $\mathrm{~b}$ \\
Flatz & 24 & $10.0 \pm 21.6$ & 0.0 & 100.0 & $\mathrm{a}$ \\
Fürstenfeld & 24 & $8.5 \pm 10.5$ & 0.2 & 38.2 & $\mathrm{~b}$ \\
Prinzersdorf & 18 & $6.8 \pm 5.1$ & 0.2 & 18.2 & $\mathrm{c}$ \\
Köszeg & 20 & $13.2 \pm 7.5$ & 1.4 & 28.4 & $\mathrm{c}$ \\
Weihenstephan & 68 & $14.0 \pm 11.7$ & 0.2 & 49.6 & $\mathrm{c}$ \\
\hline
\end{tabular}

gives a view of the geographical positions of the $I$. typographus sites.

\section{DISCUSSION}

Oversized spermatozoa formed by sperm pairing are known to occur in other coleopteran families. It is best studied in the Dytiscidae (Bawa, 1974; Werner, 1976). In this case, the flattened heads of the sperm are fused together and their tails remain free. Sperm conjugation seems to occur during the last phase of spermiohistogenesis, and these aggregates consist of haploid spermatozoa. Conjugated sperm are believed to be at an advantage when penetrating into eggs. They may also be an evolutionary precursor of sperm packaging and spermatophore formation (Jamieson, 1987). However, this kind of sperm conjugation is not identical with the formation of oversized sperm described in the Scolytidae.

In bark beetles (Scolytidae), oversized sperm were first observed by Virkki (1960) and by Lanier (1970). Virkki, who found them in a specimen from a wild population, described this phenomenon in Tomicus piniperda (L.). Lanier reported abnormal divisions of sperm cells in allopatric male hybrids of Ips grandicollis (Eichhoff), which he reared in the laboratory. Lanier \& Kirkendall (1986) described polyploidy in the spermatozoa of Ips borealis (Swaine) and in crosses between I. perturbatus (Eichhoff) and I. hunteri (Swaine). The regular occurrence of polyploid sperm in wild populations of the bark beetle species, P. chalcographus and I. typographus, has not been described before.

Karyological investigations revealed that abnormal chromosome segregation during meiosis causes bridged 


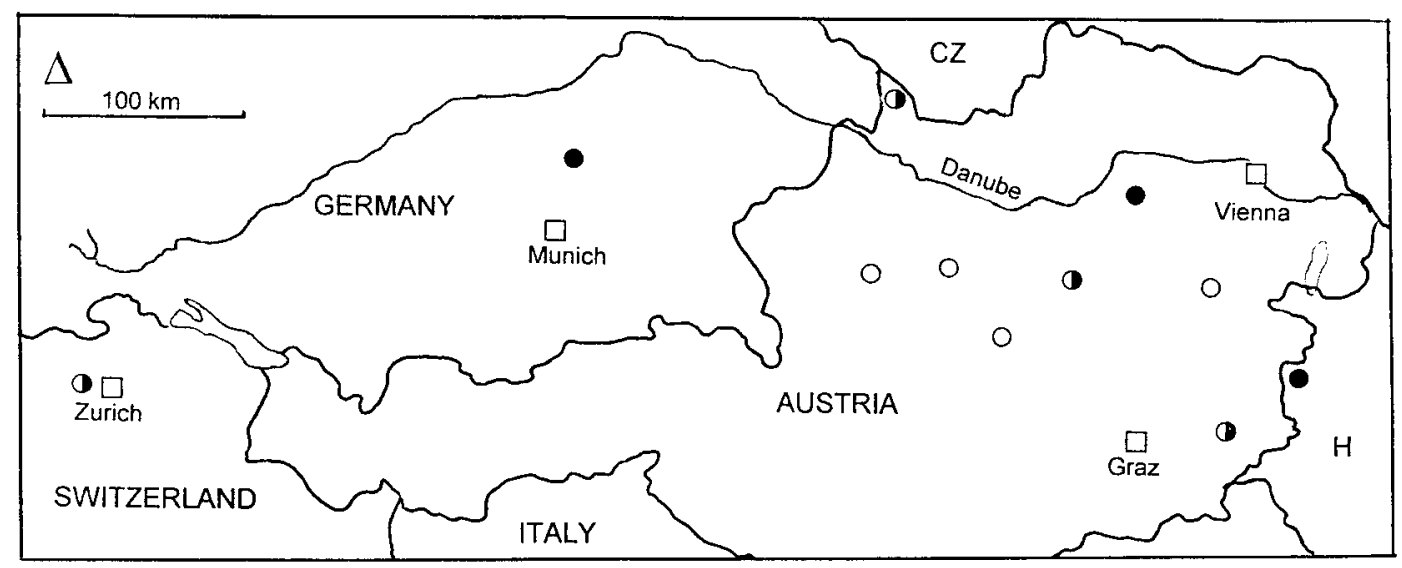

Fig. 4. Sites of I. typographus populations with low (B), medium (E) and high (C) percentages of polyploid sperm. (For levels of significance see Table 4.)

cells which later form restitution nuclei. Lanier and Kirkendall (1986) suggest that these restitution cells develop into diploid or tetraploid spermatozoa. That is, these observations do not favour an aggregation of haploid spermatozoa as in Dytiscidae, but that the oversized sperm are a product of abnormal spermatogenesis.

The same process seems to occur in $P$. chalcographus, where bridged cells were observed at meiosis in allopatric hybrids. Diploid and polyploid spermatocytes and spermatozoa were formed together with haploid cells in the same spermatocysts. Thus the abnormal cell division only affects some of the cells in a spermatocyst. Sometimes, however, whole bundles of polyploid spermatozoa develop, which may indicate that abnormal cell division occurs early in spermatogenesis. It is assumed that an identical process occurs in I. typographus. Sperm bundles with normal (haploid) and oversized sperm were observed in GIEMSA preparations.

Crosses of allopatric $P$. chalcographus resulted in an increased incidence of polyploid spermatozoa in $F_{1}$. This further supports the fact that during spermatogenesis in $F_{1}$ males either chromosomal correspondence is imperfect or the spindle apparatus does not function during cell division. That this is a sign of partial incompatibility of allopatric populations, is supported by the results of biological tests that were carried out earlier (Führer, 1977, 1978).

The frequency of polyploid spermatozoa is variable but never zero in wild populations of $P$. chalcographus. Single specimens may show a slight incidence of polyploidy even if the majority of beetles do not. Such populations were found in the northern part of Europe, i.e. in Scandinavia, Poland and Germany, and in selected areas of the Alps. They inhabit the autochthonous area of Norway spruce. Populations with a high incidence of polyploidy are found either in Central Europe or in regions where Norway spruce is grown in plantations.

High incidences of polyploid spermatozoa frequently occur in populations of $P$. chalcographus along the Danube valley, where the autochthonous Hercynian area of spruce borders the autochthonous Alpine area. Here, a migration of spruce from the Alpine to the Hercynian area has occurred; later, spruce disappeared from the Danube valley (Mayer, 1974). A disjunction developed, which was later bridged by spruce plantations. It is possible that bark beetles migrated with their host plant from the Alps into the Hercynian area and interbred with the Hercynian strains. Additionally, we can assume that after the anthropogenous closing of this gap in spruce distribution, beetles from both the Alpine and Hercynian provenance moved into this area and formed mixed populations. This could be an explanation of the present situation in $P$. chalcographus, as indicated by the incidence of polyploidy in allopatric crosses.

The frequency of polyploid spermatozoa in I. typographus is similar to that in $P$. chalcographus. Incidence of polyploidy in the Alpine area and in the foothill zone is apparently influenced in the same way as in P. chalcographus. The post-glacial distribution seems to be an important factor in the present distribution pattern of I. typographus. The occurrence of populations with a low degree of ploidy in the inner parts of the Alpine area supports this conjecture. In both species high levels of polyploidy are found in areas with allochthonous spruce stands. In addition, there has been a passive translocation of $P$. chalcographus and I. typographus by transportation of timber throughout Europe in the past. This will have contributed to the mixing of genotypes in areas heavily settled by humans, and even within areas supporting autochthonous spruce forests.

The phenomenon of sperm polyploidy raises the question: Should these cytological findings be confirmed by genetic analyses? Also, the increase in polyploidy values in $\mathrm{F}_{1}$ crosses with decrease in geographical latitude is difficult to explain without knowing the genetic status of populations in North and Central Europe. Information on the genetic status of $P$. chalcographus populations is poor (Ritzengruber, 1990), however, a further study of this subject is in progress (Stauffer, pers. comm.). In $I$. typographus, a comparison of the incidence of ploidy with phylogeographic results (Stauffer et al., 1999) is difficult because of the large differences in size of the areas. Therefore, the incidence of polyploidy in the spermatozoa of I. typographus deserves further study and should be 
accompanied by genetic investigations. The physiological reasons for the origin of partial sperm polyploidy are still unclear, as the ecological effects of polyploidy on male (and female) beetles remain to be investigated.

\section{REFERENCES}

BAwA S.R. 1974: Joined spermatozoa. In: Afzelius B.A. (ed.): The Functional Anatomy of the Spermatozoon. Pergamon Press, Oxford, pp. 259-264.

FÜHRER E. 1977: Studien über intraspezifische Inkompatibiltät bei Pityogenes chalcographus L. (Col.: Scolytidae). Z. Ang. Entomol. 83: 286-297.

FÜHRER E. 1978: Rassendifferenzierung bei Pityogenes chalcographus L. (Col.: Scolytidae). I. Morphologische Merkmale. Z. Ang. Entomol. 86: 392-402.

FÜHRER E. 1980: Spermapolyploidie durch interpopulare Bastardierung bei Pityogenes chalcographus. Naturwissenschaften 67: 410 .

FÜHRER E. 1984: Rassendifferenzierung bei Pityogenes chalcographus L. (Col.: Scolytidae). IV. Lebenserwartung interpopularer Bastarde. Cbl. Ges. Forstwes. 101: 24-33.

FÜHRER E. \& KLIPSTEIN E.-L. 1980: Rassendifferenzierung bei Pityogenes chalcographus L. (Col.: Scolytidae). III. Fertilität intraspezifischer F1-Bastarde. Forstw. Cbl. 99: 85-90.

FÜHRER E. \& KREHAN H. 1985: Zum Auftreten der Spermapolyploidie in populationen des Fichtenborkenkäfers Pityogenes chalcographus L. Cbl. Ges. Forstwes. 102: 134-149.

FüHRER E. \& MüHLENBRoCK B. 1983: Brutexperimente mit Pityogenes chalcographus L. an verschiedenen Nadelbaumarten. Z. Ang. Entomol. 96: 228-232.

Giannini R., Morgante M. \& Vendramin G.G. 1991: Allozyme variation in Italian populations of Picea abies (L.) Karst. Silvae Genetica 40: 160-166.

Hösle P., Führer E. \& Stauffer C. 2000: Molecular and ethological analysis of Ips typographus populations (Coleoptera: Scolytidae). In: Hasenauer H. (ed.): Proceedings of the International Conference on Forest Ecosystem Restoration. Ecological and Economical Impacts of Restoration Processes in Secondary Coniferous Forests. Boku, Vienna.

JAMIESON B.G.M. 1987: The Ultrastructure and Phylogeny of Insect Spermatozoa. Cambridge University Press, Cambridge, pp. 320

KLIPSTEIN E.-L. 1983: Rassendifferenzierung beim Kupferstecher (Pityogenes chalcographus L., Col.: Scolytidae) unter morphologischem, ökologischem und genetischem Aspekt. Thesis Forst. Fak. Univ. Göttingen, pp. 159.

LAGERCRANTZ U. \& RYMAN N. 1990: Genetic structure of Norway spruce (Picea abies): concordance of morphological and allozyme variation. Evolution 44: 38- 53.
LANIER G.N. 1970: Biosystematics of North American Ips (Coleoptera: Scolytidae). Hopping's Group IX. Can. Entomol. 102: 1139-1163.

LANIER G.N. \& KIRKENDALL L.R. 1986: Karyology of pseudogamous Ips bark beetles. Hereditas 105: 87-96.

Leitinger R. \& Schreiber J.D. 1992: Populationsgenetische Untersuchungen an Ips typographus L. (Coleoptera: Scolytidae) unter geographischen und verhaltenbiologischen Aspekten. Mitt. Dtsch. Ges. Allg. Angew. Entomol. 8: 348-352.

Mayer H. 1974: Wälder des Ostalpenraumes. Gustav Fischer, Stuttgart, $344 \mathrm{pp}$.

MendeLsoHn M.L. 1958: The two-wavelength method of microspectrophotometry. II: A set of tables to facilitate calculations. J. Biophys. Biochem. Cytol. 4: 415-424.

Ritzengruber O. 1990: Isoenzymanalyse verschiedener Populationen von Pityogenes chalcographus. J. Appl. Entomol. 109: $55-63$.

Ritzengruber O. \& FÜHRer E. 1986: Isoenzymanalyse verschiedener Populationen von Pityogenes chalcographus L. (Coleoptera: Scolytidae). Z. Ang. Entomol. 101: 187-194.

RomeIs B. 1968: Mikroskopische Technik. R. Oldenbourg, München, 339 pp.

Sachs L. 1973: Angewandte Statistik. Springer, Berlin, Heidelberg, New York, 545 pp.

Schmidt-Vogt H. 1974: Das natürliche Verbreitungsgebiet der Fichte (Picea abies L. Karst) in Eurasien. Allg. ForstJagdztg. 145: 185-197.

Stauffer C., Leitinger R., Simsek Z., Schreiber J. D. \& Führer E. 1992: Allozyme variation among nine Austrian Ips typographus L. (Col.: Scolytidae) populations. J. Appl. Entomol. 114: 17-25.

Stauffer C., Lakatos F. \& Hewitt G.M. 1999: Phylogeography and postglacial colonization routes of Ips typographus (Col.: Scolytidae). Mol. Ecol. 8: 763-774.

Sturies H.-J. \& FüHRER E. 1979: Rassendifferenzierung bei Pityogenes chalcographus L. (Col.: Scolytidae). II. Partnerdiskriminierung bei der Paarung. Allg. Forst-Jagdztg. 150: 99-101.

VIRKKI N. 1960: Cytology of male meiosis in certain European forest beetles of the families Scolytidae, Cleridae, and Anobiidae. Ann. Acad. Sci. Fenn., Ser. A, IV. Biologica 49: 3-18.

Werner G. 1976: Entwicklung und Bau der Doppelspermien bei den Dytisciden Acilius sulcatus L., Dytiscus marginalis L. und Hydaticus transversalis Pont. (Coleoptera). Zoomorphologie 83: 49-87.

Received February 17, 2003; revised September 10, 2003; accepted November 5, 2003 